\title{
Evaluation of Fertilizer Rates and Weed Infestation on Yield and Economic Return of Cassava-Maize Intercrop in Savanna Ecology of Nigeria
}

\author{
M.S. Ejalonibu ${ }^{1}$ and F. O.Takim ${ }^{2 *}$
}

\begin{abstract}
The low yields of maize-cassava intercrop in sub-Saharan Africa are due to some identified constraints like the poor density of component crop(s), inappropriate application of fertilizer and weed infestation among others. This study was conducted in Otukpo and Igbariam in the Derived Savanna ecology of Nigeria during the 2018 and 2019 cropping seasons to determine the impact of fertilizer rates on weed growth and yield of cassava/maize intercrop. The trials were laid out as a Randomized Complete Block Design with four replications. Cassava (TME 419) was planted as $1 \mathrm{~m} \times 0.8 \mathrm{~m}(12,500$ plants ha-1) while maize (SAMMAZ 35 ) was sowed using two different spacing $1 \mathrm{~m} \times 0.5 \mathrm{~m}$ and $1 \mathrm{~m} \times 0.25 \mathrm{~m}$ to give an approximately plant population of 20,000 plants/ha and 40,000 plants/ha, respectively.
\end{abstract}

${ }^{1}$ National Root Crops Research Institute Umudike, P. M. B. 7006, Umuahia, Nigeria.

${ }^{2}$ Department of Agronomy, University of Ilorin, P.M.B. 1515, Ilorin, Nigeria.

*fotakimson@unilorin.edu.ng

(iD) http://orcid.org/0000-0001-6992-5106

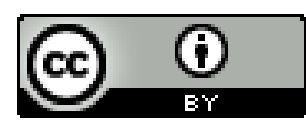

This article is published under the terms of the Creative Commons Attribution 4.0 International License which permits unrestricted use, distribution and reproduction in any medium provided the original author and source are credited.
NPK-fertilizer was applied as 90:20:40 $\mathrm{kg} / \mathrm{ha}$ and 75:20:90 kg/ha. Data collected on weed density and weed biomass, maize grains yield and cassava root yield were subjected to analysis of variance at $P$ $\leq 0.05$. The benefit-cost ratio also was calculated. Results showed that weeds emerged throughout the growing season with a peak at 8 weeks after planting (WAP). Ageratum houstonianum, Cyperus rotundus, Digitaria horizontalis, Lindernia crustacea, Stachytapheta jamaicensis and Oldenlandia corymbosa were the most prevalent weed species. Intercropping cassava at 12,500 plants/ha and maize at 40,000 plants/ha with 90:20:40 $\mathrm{kg} / \mathrm{ha}$ of NPK gave the highest economic return of $535,064.00-618,614.00$ (US\$ $1,301.95$ - 1,505.21) and production efficiency of $28-31 \%$ per hectare. This study concludes that intercropping 12,500 plants/ha of cassava and 40,000 plants/ha of maize with the application of 90:20:40 $\mathrm{kg} / \mathrm{ha}$ of NPK relatively reduces weed growth and gives a higher intercrop yield with good economic returns in the derived savannah ecology of Nigeria.

Keywords: Crop yield, Derived savannah, Economic return, Nigeria, Weed emergence. 


\section{INTRODUCTION}

Cassava (Manihot esculenta Crantz.) is a root crop usually intercropped with crops such as maize, cowpea, egusimelon in Nigeria. The benefits derived from intercropping includes; greater combined crop yields (Essien, 2018), utilization of farm resources (Chinaka and Obiefuna, 2000), food security (Yusuf et al., 2008), an increase in land productivity (Mucheru-Muna et al., 2010) weed suppression and economical weed control (Makoi and Ndakidemi, 2012).

Weeds as led to severe yield losses when uncontrolled, Korieocha (2014) reported $50-100 \%$ lost in cassava tuber yield while Iyagba (2010) revealed that, such a loss usually depends on the weed spectrum of the field. The suppression of weeds in an intercropping system may be through competition for growth resources or allelopathy (Arora et al., 2015). Cassavamaize intercrop is one of the effective means of suppressing arable weeds (Negash and Mulualem, 2014) although there is a need to establish the optimum plant density of intercrop components (Olorunmaiye et al.,2013) and apply recommended type and rate of fertilizer to enable a speedy canopy closure suitable for better weed suppression (Okeleye and Salawu, 1999). This study, therefore, aimed to evaluate the effect of two maize populations and N, P and $\mathrm{K}$ fertilizer rates on weed population and yield of cassava/maize intercrop in savannah ecology of Nigeria.

\section{MATERIALS AND METHODS}

This study was conducted at Otukpo $\left(07^{\circ} 10^{\prime} \mathrm{N}, \quad 08^{\circ} 39^{\prime} \mathrm{E}\right)$ and Igbariam $\left(06^{\circ} 15^{\prime} \mathrm{N}, 06^{\circ} 52^{\prime} \mathrm{E}\right)$, both in the Derived Savanna Agro-ecology of Nigeria during the 2018 and 2019 cropping seasons. The annual average rainfall was about $1000 \mathrm{~mm}-1200 \mathrm{~mm}$ and the mean temperature ranged from $25.5^{\circ} \mathrm{C}$ - to $27.2^{\circ} \mathrm{C}$. The trials were laid out as Randomized Complete Block Design in a factorial arrangement with four replications. The treatment combinations were as follows.
(i) 12,500 plants/ha cassava $+40,000$ plants/ha maize $+75: 20: 90 \mathrm{~kg} / \mathrm{ha}$ NPK $\left(\mathrm{CM}_{1} \mathrm{~F}_{1}\right)$

(ii) 12,500 plants/ha cassava $+20,000$ plants/ha maize $+75: 20: 90 \mathrm{~kg} / \mathrm{ha}$ NPK $\left(\mathrm{CM}_{2} \mathrm{~F}_{1}\right)$

(iii) 12,500 plants/ha cassava $+75: 20: 90$ $\mathrm{kg} / \mathrm{ha} \mathrm{NPK}\left(\mathrm{CF}_{1}\right)$

(iv) 12,500 plants/ha cassava $+90: 20: 40$ $\mathrm{kg} / \mathrm{ha} \mathrm{NPK}\left(\mathrm{CF}_{2}\right)$

(v) 12,500 plants/ha cassava $+40,000$ plants/ha maize + no fertilizer $\left(\mathrm{CM}_{1}\right)$ 
(vi) 40,000 plants/ha maize $+90: 20: 40$ $\mathrm{kg} / \mathrm{ha}$ NPK $\left(\mathrm{M}_{1} \mathrm{~F}_{2}\right)$

(vii) 12,500 plants/ha cassava $+40,000$ plants/ha maize + 90:20:40 kg/ha NPK $\left(\mathrm{CM}_{1} \mathrm{~F}_{2}\right)$

(viii) 12,500 plants/ha cassava $+20,000$ plants/ha maize + no fertilizer $\left(\mathrm{CM}_{2}\right)$

(ix) 12,500 plants/ha cassava $+20,000$ plants/ha + 90:20:40 kg/ha NPK $\left(\mathrm{CM}_{2} \mathrm{~F}_{2}\right)$

(x) 20,000 plants/ha maize $+90: 20: 40$ $\mathrm{kg} / \mathrm{ha}$ NPK $\left(\mathrm{M}_{2} \mathrm{~F}_{2}\right)$

The field (0.23 ha) was ploughed, harrowed and ridged using a tractor. Cassava (TME 419) stems were caught $20-25 \mathrm{~cm}$ stakes and planted on ridge crests $15 \mathrm{~cm}$ deep into the soil in a slanted position. The stakes were planted $1 \mathrm{~m} \times 0.8 \mathrm{~m}\left(12,500\right.$ plants ha- $\left.{ }^{1}\right)$ apart while maize (SAMMAZ 35) was sowed using 2 different spacing $1 \mathrm{~m} \mathrm{x}$ $0.5 \mathrm{~m}$ and $1 \mathrm{~m} \times 0.25 \mathrm{~m}$ to give an approximately plant population of 20,000 plants ha- ${ }^{1}$ and 40,000 plants ha1 , respectively. Primextra [proprietary mixture of metolachlor (290 g/L) and atrazine $(370 \mathrm{~g} / \mathrm{L})]$ was applied as preemergence at $2.5 \mathrm{~kg}$ ai $/$ ha immediately after seeding using a CP3 knapsacks sprayer filter with a polyjet nozzle with a delivery rate of 250-300 L/ha and a supplementary hand hoeing at $6-7$ weeks after planting (WAP). Fertilizer was applied at the rate of $90 \mathrm{~kg} \mathrm{~N}, 20 \mathrm{~kg}$ $\mathrm{P}$ and $40 \mathrm{~kg} \mathrm{~K} \mathrm{ha-}{ }^{1}$ (using $133 \mathrm{~kg}$ of NPK
15:15:15, $152 \mathrm{~kg}$ of Urea and $33 \mathrm{~kg}$ of Muriate of Potash) and $75 \mathrm{~kg} \mathrm{~N}, 20 \mathrm{~kg} P$ and $90 \mathrm{~kg} \mathrm{~K} \mathrm{ha-}{ }^{1}$ (using $133 \mathrm{~kg}$ of NPK $15: 15: 15,120 \mathrm{~kg}$ of Urea and $117 \mathrm{~kg}$ of Muriate of Potash).

Data were collected on weed density and weed biomass at 4, 8, 12, 16 and 20 WAP using fixed quadrat $\left(1 \mathrm{~m}^{2}\right.$ per plot) at each assessment period (Takim and Fadayomi, 2010). At each assessment period, weeds were counted, pulled out and identified into species level using Weed Identification Manual of Akobundu et al. (2016). The pulled weeds within each quadrat were oven-dried till the weight becomes constant. Grain and root yield were taken at harvest. Important value index (IVI) was determined as IVI = relative frequency + relative density + relative abundance (Takariha et al., 2016) as follows, where,

$$
\begin{aligned}
& \text { Relative frequency }= \\
& \frac{\text { total number of quadrat in which species occurred }}{\text { total number of occurence of all the species }} \times 100 \text {, } \\
& \text { Relative density }= \\
& \frac{\text { number of individual of a species }}{\text { number of individual of all the species }} \times 100 \text { and } \\
& \text { Relative abundance (Dominance) } \\
& \quad \frac{\text { total basal area of a species }}{\text { total basal area of all the species }} \times 100 .
\end{aligned}
$$


All the data collected on weeds and crops were subjected to analysis of variance at $P<0.05$.

The data obtained on the cost of farm inputs and revenues from the output of maize were analysed using addition, mean and percentages. Gross margin was used to determine the profitability of the intercropping system. The assumption was that, the farmers are rural dwellers that inherited the farmland and depend only on hoes, cutlasses and the hiring of tractors for tillage operations. Those farm tools had negligible depreciation and so were ignored in the computation of costs of production. Gross Margin was obtained by deducting the total cost from total revenue. The efficiency of intercropping cassava-maize and fertilizer rates were calculated by dividing total cost by total revenue and multiplying by 100 . The benefit-cost ratio was obtained by dividing benefit by cost.

\section{RESULTS AND DISCUSSION}

\section{Weed Species Composition}

Thirty-one weed species within 27 genera belonging to 16 families were encountered during the study (Table 1).
The weed community is comprised of $67.74 \%$ annuals, $25.81 \%$ perennials and $6.46 \%$ annual/perennial weed species. Grasses were $12.90 \%$ and broadleaves and sedges were $83.87 \%$ and $3.23 \%$, respectively. Based on IVI, the five (5) most prevalent weed species in Igbariam were Ageratum houstonianum Mill. (96.29), Cyperus rotundus Linn. (35.84), Oldenlandia corymbosa Linn. (16.95), Digitaria horizontalis Willd. (16.95) and Paspalium scrobiculatum Linn. (16.6) while Lindernia crustacea (L.) F. Muell. (59.35), Stachytapheta jamaicensis (Linn.) Vahl. (37.30), Oldenlandia corymbosa Linn. (27.33), Spilanthes costata Benth. (26.58) and Melochia corchorifolia Linn. (22.38) were in Otukpo. The high number of emerged weed species encountered could be attributed to the fact that both 
Table 1. Important Value Index (IVI) of weed species encountered at trial sites

\begin{tabular}{|c|c|c|c|c|c|}
\hline \multirow[t]{2}{*}{ Family } & \multirow[t]{2}{*}{ Weed species } & \multirow[t]{2}{*}{ MG } & \multirow[t]{2}{*}{ LC } & \multirow{2}{*}{$\begin{array}{l}\text { IVI } \\
\text { Igbariam }\end{array}$} & \multirow{2}{*}{$\begin{array}{l}\text { IVI } \\
\text { Otukpo }\end{array}$} \\
\hline & & & & & \\
\hline \multirow[t]{6}{*}{ Asteraceae } & Acanthospermum hispidium DC. & $\mathrm{B}$ & A & 12.62 & - \\
\hline & Ageratum conyzoides Linn. & $\mathrm{B}$ & $\mathrm{A}$ & - & 8.52 \\
\hline & A. houstonianum Mill. & $\mathrm{B}$ & A & 96.29 & - \\
\hline & Aspilia africana (Pers.) C.D. Adams. & $\mathrm{B}$ & $\mathrm{P}$ & - & 4.78 \\
\hline & Spilanthes costata Benth. & $\mathrm{B}$ & $\mathrm{A}$ & - & 26.58 \\
\hline & Vicoa leptoclada (Webb) Dandy. & B & A & - & 9.07 \\
\hline \multirow[t]{2}{*}{ Cleomaceae } & Cleome rotidosperma D.C. & $\mathrm{B}$ & A & 7.52 & - \\
\hline & C. viscosa L. & $\mathrm{B}$ & A & 5.08 & - \\
\hline Commelinaceae & Commelina diffusa Burm. F.subsp. & $\mathrm{B}$ & $\mathrm{A} / \mathrm{P}$ & 7.86 & - \\
\hline Convolvulaceae & Ipomoea involucrata P. Beauv. & $\mathrm{B}$ & $\mathrm{A} / \mathrm{P}$ & - & 4.07 \\
\hline Cyperaceae & Cyperus rotundus Linn. & S & $\mathrm{P}$ & 35.84 & 4.7 \\
\hline \multirow[t]{2}{*}{ Euphobiaceae } & Euphorbia heterophylla Linn. & $\mathrm{B}$ & A & - & 4.96 \\
\hline & E. hirta Linn. & $\mathrm{B}$ & A & 1.24 & 2.23 \\
\hline \multirow[t]{2}{*}{ Lamiaceae } & Hyptis suaveolens Poit & $\mathrm{B}$ & $\mathrm{A}$ & 4.78 & 2.97 \\
\hline & Solenostermon monostachyus (P.Beauv.) Brig. & $\mathrm{B}$ & A & 7.09 & - \\
\hline
\end{tabular}




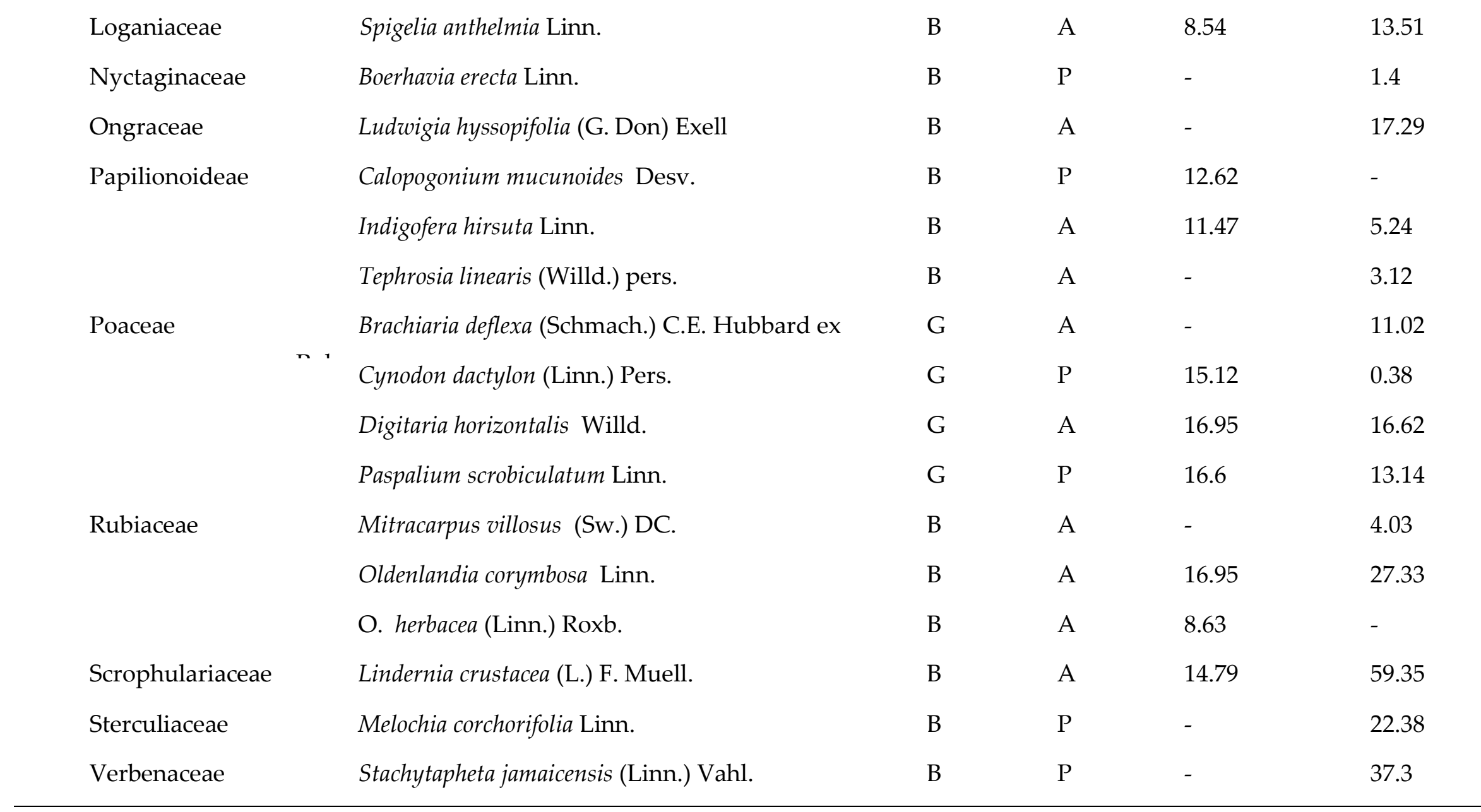

$M G=$ Morphological group,$L C=$ Life cycle, $I V I=$ important value Index, $G=$ grass, $B=$ broadleaved, $S=$ sedge, $A=$ annual, $P=$ perennial,$(-)=$ absent 
sites had been under continuous cultivations mainly for more than four years before the commencement of this study. Ekeleme et al. (2004) reported that weed emergence was greater in the lands under continuous cultivation and cultivated every other year than a site that was cultivated once and left for fallow. Takim and Fadayomi (2010) observed that the high density of weed species shows the effect of continuous cultivation in replenishing the soil weed seed bank.

Weeds emerged throughout the crop growing periods, weed population and biomass sharply increased giving the peak at 8WAP and declined gradually (Figure 1 and 2). Takim and Fadayomi (2013) reported that 3, 8 and 10WAP are likely the peaks of weed emergence on arable crop fields in southern Guinea savannah. There was a relatively high weed density and biomass in the first few weeks after planting across the cropping systems and significantly higher in sole plots compared to the intercropped plots at 6WAP and above. This is in line with Takim (2012) who reported that the population of weeds in most of the intercropped treatments reduced as the cropping season advanced. The above trend might be due to the fact that cassava growth was slow initially and the maize also struggled to establish, weeds, therefore, make use of that opportunity to thrive. Azevêdo et al (2000) reported that initially, the slow growth of cassava facilitates weed species to develop the mechanism for the competition of gaining resources and space. Okeleye and Salawu (1999) further explained that, as the plant grows, the whole canopy cover becomes denser and shelters the ground better. It may, therefore, reduces solar radiation reaching the ground, which is detrimental for the understory weeds. Hence, the reduction in weed density could be observed in the cassava-based intercrop at 5 WAP (Amanullah et al., 2006; Olorunmaiye et al., 2013). Weed density and dry matter were relatively lower in plots where 12, 500 plants/ha of cassava and 40,000 plants/ha of maize were established. A similar finding was reported by Adeniyan, et al. (2014), who showed a relatively high density of maize plants ha-1 $(40,000)$ with 10,000 cassava plants/ha was suitable for better weed suppression.

\section{Crop Yield}

Effect of cassava intercropping system affected the grain and root yield 


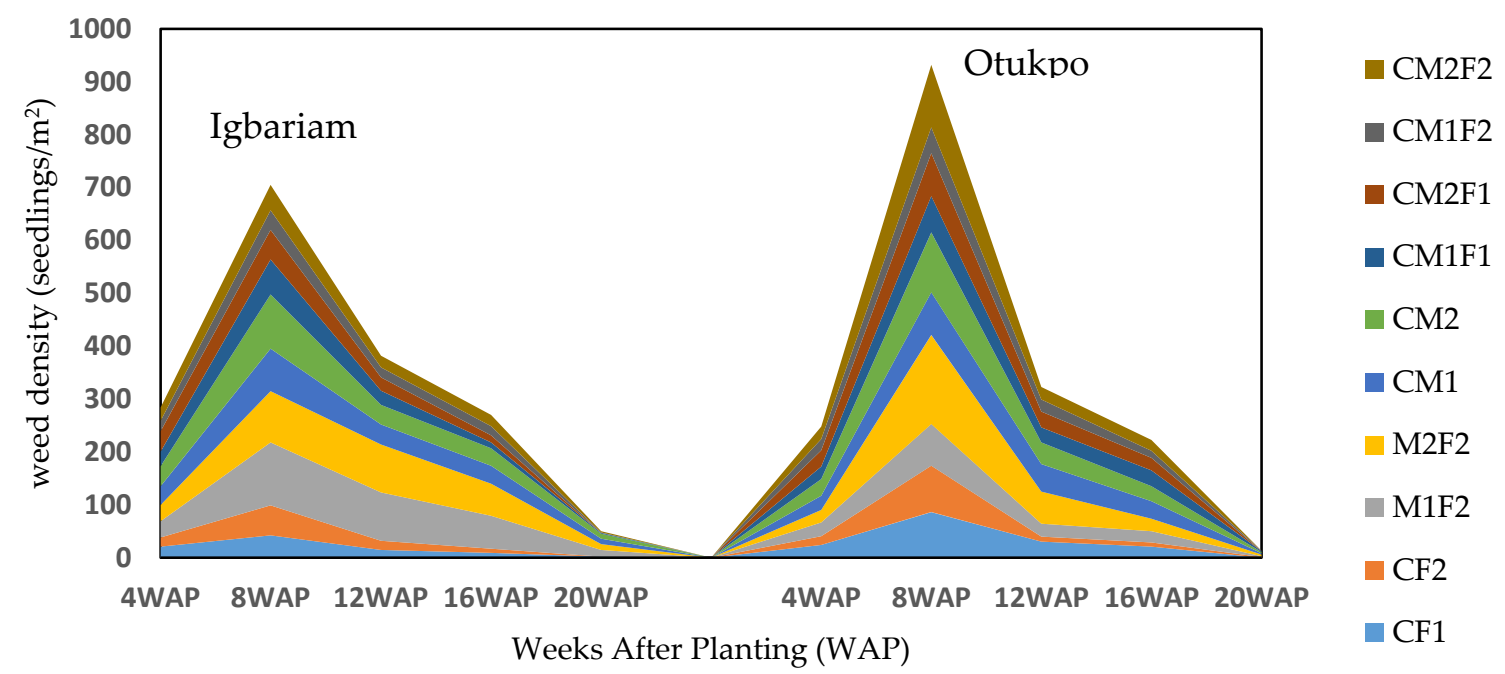

Figure 1. Effect of cassava-maize intercrop on weed density in Igbariam and Otukpo sites; $C=$ Cassava $(12,500$ plant ha-1), M1 = Maize (40,000 plants ha-1), M2= Maize (20,000 plants ha- $\left.{ }^{1}\right), F 1=N P K\left(75: 20: 90 \mathrm{~kg} \mathrm{ha}^{-1}\right), F 2=N P K\left(90: 20: 40 \mathrm{~kg} \mathrm{ha}^{-1}\right)$

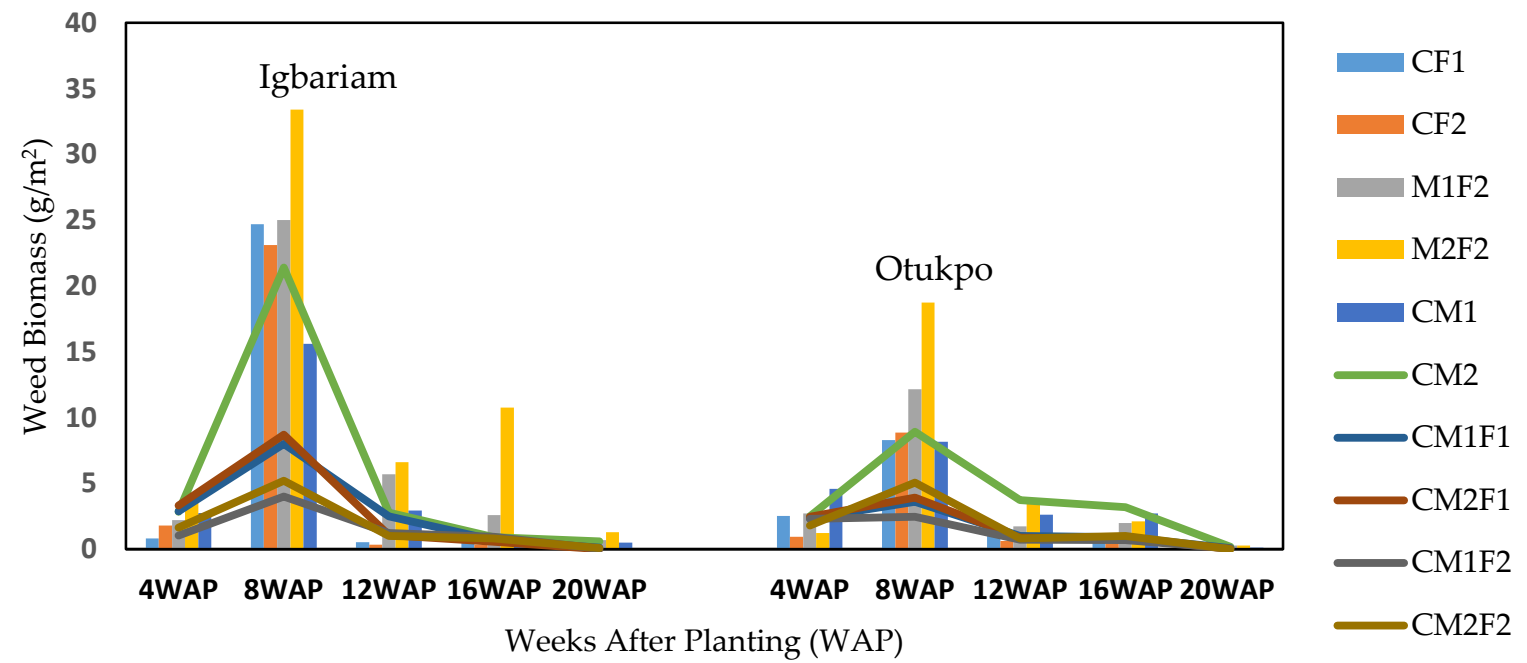

Figure 2. Effect of cassava-maize intercrop on weed biomass in Igbariam and Otukpo sites; $C=$ Cassava (12,500 plant ha-1), M1= Maize (40,000 plants ha-1), M2= Maize (20,000 plants ha-1), $F_{1}=$ NPK (75:20:90 $\left.\mathrm{kg} \mathrm{ha}^{-1}\right), F 2=\operatorname{NPK}\left(\right.$ 90:20:40 $\left.\mathrm{kg} \mathrm{ha}^{-1}\right)$ 
(Table 2). Plots with high maize population and fertilizer rate had significantly higher grain yields compared to others. The maize component of the intercropped plots had grain yield which ranged between 1.42 to 2.11 ton/ha with no fertilizer application, $2.95-4.25$ ton/ha at 40,000 plants/ha with low fertilizer rate and 2.20 to 2.58 ton/ha at 20,000 plants/ha with high fertilizer rate. Adeniyan et al., (2014) also reported that significantly higher maize grain yield (3.28-3.55 ton/ha) could be obtained at 40,000 plants/ha. We noted that yield of cassava component increased with a reduction in maize population at optimum fertilizer dose and this fact was in line with Agbaje and Akinlosotu (2004), Issaka et al. (2007), Ojeniyi et al. (2012) and Ezui et al. (2016). The high yields obtained in the sole cropped plots as compared to the intercropped plots agreed with Takim and Fadayomi (2010) who reported that the sole plots produced better yield than their intercropped components, although the economic value of the yields of intercropped plots was significantly higher than that of sole crop plots.

\section{Economic Estimation}

Table 3 shows the economic estimate based on cassava-maize intercrop and sole cropping of maize and cassava and the result indicates that the total production cost at both sites ranged between $\$ 180,936$ and $\$ 260,936$ depending on the rate of fertilizer applied. The profit per hectare for intercropping system ranged from $\$ 526,644.00$ to $\$ 618, \quad 614.00$ and $\$ 399,064.00$ to $\$ 535,064.00$ at Igbariam and Otukpo, respectively while the benefit-cost ratio for Igbariam was estimated at $2.08-2.55$ and it was $1.58-2.20$ for Otukpo. This implies that for every Naira invested on cassavamaize production with any of the fertilizer rate evaluated, 1.58 to 2.55 will be generated depending on the location. The production efficiency shows that $28.19-32.44 \%$ (Igbariam) and 31.23-38.73\% (Otukpo) of all revenue generated for the cassavamaize enterprise went into cost of production.

\section{CONCLUSION}

This study concludes that, preemergence application of Primextra and a supplementary weed control targeted at the peak of weed emergence 
(8WAP) could relatively reduce weed growth in cassava-maize intercrop. The optimum population of 12,500 plants/ha and maize 40,000 at plants/ha with application of 90:20:40 kg/ha of NPK gave a higher economic return of
\$535,064.00 - 618,614.00 (US\$1,301.95 $1,505.21)$ and production efficiency 28 $31 \%$ per hectare. The above treatment combination should be adopted for cassava-maize intercropping in derived savannah ecology of Nigeria.

Table 2. Effect of cassava-maize intercrop and fertilizer rate on the yield component of crops

\begin{tabular}{|c|c|c|c|c|}
\hline \multirow[b]{2}{*}{$\begin{array}{l}\text { Treatment } \\
\text { Combination }\end{array}$} & \multicolumn{2}{|c|}{ Igbariam } & \multicolumn{2}{|c|}{ Otukpo } \\
\hline & $\begin{array}{l}\text { Root Yield } \\
\text { (tons/ha) }\end{array}$ & $\begin{array}{l}\text { Grain } \\
\text { Yield } \\
\text { (tons/ha) }\end{array}$ & $\begin{array}{l}\text { Root Yield } \\
\text { (tons/ha) }\end{array}$ & $\begin{array}{l}\text { Grain } \\
\text { Yield } \\
\text { (tons/ha) }\end{array}$ \\
\hline CF1 & 24.74 & - & 24.16 & - \\
\hline CF2 & 21.85 & - & 25.10 & - \\
\hline CM1 & 11.41 & 1.42 & 10.57 & 1.69 \\
\hline CM2 & 15.94 & 2.11 & 11.53 & 1.49 \\
\hline M1F2 & - & 3.77 & - & 3.91 \\
\hline M2F2 & - & 2.79 & - & 3.15 \\
\hline CM1F1 & 20.30 & 2.95 & 11.76 & 2.95 \\
\hline $\mathrm{CM} 2 \mathrm{~F} 1$ & 22.34 & 2.20 & 15.82 & 2.40 \\
\hline CM1F2 & 16.75 & 3.69 & 10.72 & 4.25 \\
\hline $\mathrm{CM} 2 \mathrm{~F} 2$ & 19.52 & 2.43 & 16.27 & 2.58 \\
\hline Sed (0.05) & $2.70^{*}$ & $0.54^{*}$ & $1.95^{*}$ & $0.27^{*}$ \\
\hline
\end{tabular}


Table 3: Economic analysis of cassava-maize intercrop in derived Savannah of Nigeria

\begin{tabular}{|c|c|c|c|c|c|c|c|c|c|}
\hline $\begin{array}{l}\text { Treatment } \\
\text { Combination }\end{array}$ & $\begin{array}{c}\text { Cassava } \\
\text { Yield } \\
\text { (tons/ha) }\end{array}$ & $\begin{array}{c}\text { Grain } \\
\text { yield } \\
\text { (tons/ha) }\end{array}$ & $\begin{array}{l}\text { Current } \\
\text { price of } \\
\text { Cassava } \\
\text { (\$/ton) }\end{array}$ & $\begin{array}{c}\text { Current } \\
\text { price of } \\
\text { grain } \\
\text { (\$/ton) }\end{array}$ & $\begin{array}{c}\text { Cost of } \\
\text { production } \\
(\mathbf{A} / \mathrm{ha})\end{array}$ & $\begin{array}{c}\text { Total } \\
\text { revenue } \\
\text { (\#) }\end{array}$ & $\begin{array}{c}\text { Profit } \\
\text { (A) }\end{array}$ & $\begin{array}{c}\text { Benefit } \\
\text { cost ratio }\end{array}$ & $\begin{array}{c}\text { Performance } \\
\text { efficiency } \\
(\%)\end{array}$ \\
\hline & \multicolumn{9}{|c|}{ Igbariam } \\
\hline $\mathrm{CM}_{1}$ & 11.41 & 1.42 & 25000 & 120000 & 187936 & 455650 & 267714 & 1.43 & 41.25 \\
\hline $\mathrm{CM}_{1} \mathrm{~F}_{1}$ & 20.30 & 2.95 & 25000 & 120000 & 250936 & 861500 & 610564 & 2.43 & 29.13 \\
\hline $\mathrm{CM}_{1} \mathrm{~F}_{2}$ & 16.75 & 3.69 & 25000 & 120000 & 242936 & 861550 & 618614 & 2.55 & 28.19 \\
\hline $\mathrm{M}_{1} \mathrm{~F}_{2}$ & -- & 3.77 & 25000 & 120000 & 180936 & 452400 & 271464 & 1.50 & 39.99 \\
\hline $\mathrm{CM}_{2}$ & 15.94 & 2.11 & 25000 & 120000 & 197936 & 651700 & 453764 & 2.29 & 30.37 \\
\hline $\mathrm{CM}_{2} \mathrm{~F} 1$ & 22.34 & 2.20 & 25000 & 120000 & 260936 & 822500 & 561564 & 2.15 & 31.72 \\
\hline $\mathrm{CM}_{2} \mathrm{~F}_{2}$ & 19.52 & 2.43 & 25000 & 120000 & 252936 & 779600 & 526664 & 2.08 & 32.44 \\
\hline $\mathrm{M}_{2} \mathrm{~F}_{2}$ & -- & 2.79 & 25000 & 120000 & 190936 & 334800 & 143864 & 0.75 & 57.03 \\
\hline $\mathrm{CF}_{1}$ & 24.74 & -- & 25000 & 120000 & 211936 & 618500 & 406564 & 1.92 & 34.27 \\
\hline $\mathrm{CF}_{2}$ & 21.85 & -- & 25000 & 120000 & 203936 & 546250 & 342314 & 1.68 & 37.34 \\
\hline
\end{tabular}


M.S. Ejalonibu and F. O.Takim

\begin{tabular}{lccccccccc}
\hline & \multicolumn{7}{c}{ Otukpo } \\
\hline $\mathrm{CM}_{1}$ & 10.57 & 1.69 & 25000 & 120000 & 187936 & 467050 & 279114 & 1.48 & 40.24 \\
$\mathrm{CM}_{1} \mathrm{~F}_{1}$ & 11.76 & 2.95 & 25000 & 120000 & 250936 & 648000 & 397064 & 1.58 & 38.73 \\
$\mathrm{CM}_{1} \mathrm{~F}_{2}$ & 10.72 & 4.25 & 25000 & 120000 & 242936 & 778000 & 535064 & 2.20 & 31.23 \\
$\mathrm{M}_{1} \mathrm{~F}_{2}$ & -- & 3.91 & 25000 & 120000 & 180936 & 469200 & 288264 & 1.59 & 38.56 \\
$\mathrm{CM}_{2}$ & 11.53 & 1.49 & 25000 & 120000 & 197936 & 467050 & 269114 & 1.35 & 42.38 \\
$\mathrm{CM}_{2} \mathrm{~F}_{1}$ & 15.82 & 2.40 & 25000 & 120000 & 260936 & 683500 & 422564 & 1.62 & 38.18 \\
$\mathrm{CM}_{2} \mathrm{~F}_{2}$ & 16.27 & 2.58 & 25000 & 120000 & 252936 & 716350 & 463414 & 1.83 & 35.31 \\
$\mathrm{M}_{2} \mathrm{~F}_{2}$ & -- & 3.15 & 25000 & 120000 & 190936 & 378000 & 187064 & 0.98 & 50.51 \\
$\mathrm{CF}_{1}$ & 24.16 & -- & 25000 & 120000 & 211936 & 604000 & 392064 & 1.85 & 35.09 \\
$\mathrm{CF}_{2}$ & 25.10 & -- & 25000 & 120000 & 203936 & 627500 & 423564 & 2.077 & 32.49 \\
\hline
\end{tabular}

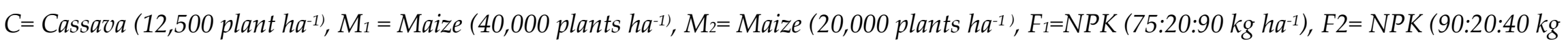
$h a^{-1}$ ) 


\section{REFERENCES}

Adeniyan, O. N., Aluko, O. A., Olanipekun, S. O., Olasoji, J. O. and Aduramigba-modupe, V. O. (2014). Growth and yield performance of cassava/maize intercrop under different plant population density of maize. Journal of Agricultural Science, 6(8): $35-40$.

Agbaje, G. O. and Akinlosotu, T. A. (2004). Influence of NPK fertilizer on tuber yield of early and late-planted cassava in a forest alfisol of southwestern Nigeria. African Journal of Biotechnology, 3(10): 547 - 551.

Akobundu, I. O., Ekeleme, F., Agyakwa, C. W. and Ogazie, C. A. (2016). A handbook of West Africa weeds ( $3^{\text {rd }}$ edition, pp. 345). International Institute of Tropical Agriculture, Ibadan Nigeria.

Amanullah, M., Alagesan, A., Vaiyapuri, K., Pazhanivelan, S. and Sathyamoorthi, K. (2006). Intercropping and organic manures on growth and yield of cassava (Manihot esculenta Crantz). Resources Journal of Agricultural and Biological Science, 2: 183- 189.

Arora, K., Batish, D. R., Singh, H. P. and Kohli, R. K. (2015). Allelopathic potential of the essential oil of wild marigold (Tagetes minuta L.) against some invasive weeds. Journal of Environmental and Agricultural Science. 3: 56- 60.

Azevedo, C. L. L., Carvalho, J. E. B., Lopes, L. C. and Araujo, A. M. A.
(2000). Weed survey in cassava crop in a semi-arid ecosystem in the state of Bahia. Magistrate, 12(1): 41-49.

Chinaka, C. C. and Obiefuna, J. C. (2000). Evaluation of optimum population and biological efficiency of sweet potato/maize intercropping system. Nigerian Agricultural Journal, 31: $158-165$.

Ekeleme, F., Chikoye, D. and Akobundu, I. O. (2004). Changes in size and composition of weed communities during planted and natural fallows. Basic and Applied Ecology, 5: 25 - 33 .

Essien, B. A. (2018). Response of cassava/maize/groundnut based intercropping systems in the derived savanna of south-eastern Nigeria. The Melting Pot, 2(1): 1 - 14.

Ezui, K. S., Franke, A. C., Mando, A., Ahiabor, B. D. K., Tetteh, F. M., Sogbedji, J., Janssen, B. H. and Giller, K. E. (2016). Fertilizer requirements for balanced nutrition of cassava across eight locations in West Africa. Field Crops Resources, 185: 69-78.

Issaka, R. N., Buri, M. M., Asare, D., Senayah, J. K. and Essien, M. A. (2007). Effects of cropping system and mineral fertilizer on root yield of cassava. Agricultural Food Science Journal Ghana, 6: $445-458$.

Iyagba, A. G., (2010). A review on root and tuber crop production and their weed management among small scale farmers in Nigeria. Journal of 
Agricultural E Biological Science, 5(4): $52-58$.

Korieocha, D. S. (2014). Weed control in national root crops research institute Umudike and its recommendation. Resources Journal of Agricultural and Environmental Management, 4(1): 1 - 4 .

Makoi, J. H. J. R. and Ndakidemi, P. A. (2012). Allelopathy as protectant, defence and growth stimulants in legume cereal mixed culture systems. New Zealand Journal of Crop and Horticultural Science, 40(3): 1 26.

Mucheru-Muna, M., Pypers, P., Mugendi, D., Kung'u, J., Mugwe, J., Merckx, R. and Vanlauwe, B. (2010). A staggered maize-legume intercrop arrangement robustly increases crop yields and economic returns in the highlands of Central Kenya. Field Crops Research, 115(2): $132-139$.

Negash, F. and Mulualem, T. (2014). Enhanced land use system through cassava/maize intercropping in south region of Ethiopia. Sky Journal of Agricultural Research, 3(10), 196 200.

Ojeniyi S. O., Samson, A. O., Odedina, J. N. and Akinlana, F. (2012). Effect of different organic nutrient sources and two NPK rates on the performance and nutrient contents of a newly released cassava variety. Journal of Life Sciences, 6: 1003 - 1007.

Okeleye, K. A., and Salawu, R. A., (1999). Use of low growing crops as an alternative weed control measure in Cassava-based cropping system in Southern Nigeria. Nigerian Journal of Weed Science, 12: 17 - 22.

Olorunmaiye, P. M., Lagoke, S. T. O., Adigun, J. A. and Orija, O. R. (2013). Effect of intercropping with maize on weed diversity in cassava. Environmental of Experimental Biology, 11: 189 - 193.

Takariha, A., Shrivastava1, A. K. and Patra, S. (2016). Phytosociological analysis of weeds in Durg district of Chhattisgarh. Journal of Environmental Science, Toxicology and Food Technology, 10(10): $14-21$.

Takim, F. O. (2012). Advantages of maize-cowpea intercropping over sole cropping through competition indices. Journal of Agriculture and Biodiversity Research, 1(4): 53 - 59.

Takim, F. O. and Fadayomi, O. (2010). Influence of tillage and cropping systems on field emergence, growth of weeds and yield of maize (Zea mays L.) and cowpea (Vigna unguiculata L). Australian Journal of Agricultural Engineering, 1(4): 141 148.

Takim, F. O. and Fadayomi, O. (2013). Pattern of field emergence of weeds in an arable field in the southern Guinea savanna ecology of Nigeria. Nigerian Journal of Weed Science, 26: 53-63.

Yusuf, O., Sanni, S. A., Ojuekaiye, E. O. and Ugbabe, O. O. (2008). Profitability of 'Egusi' melon (Critrullus lanatus Thunb, Mansf.) 
production under sole and mixed cropping systems in Kogi State, Nigeria. ARP Nigerian Journal of Agricultural and Biological Science, 3: $14-18$. 